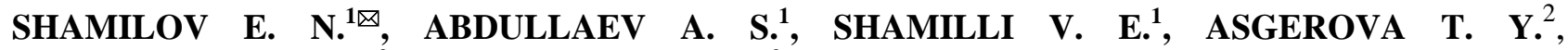 \\ GAHRAMAN VA Sh. I. ${ }^{2}$, JALALADDINOV F. F. ${ }^{2}$ \\ ${ }^{1}$ Institute of Radiation Problems of ANAS, \\ Azerbaijan Republic, AZ1143, Baku,B.Vahabzadeh, 9, e-mail:elshanshamil@gmail.com \\ ${ }^{2}$ Institute of Catalysis and Inorganic Chemistry named after Acad. M.F. Nagiyev ANAS, \\ Azerbaijan Republic, AZ1143, Baku, Huseyn Javid ave., 113 \\ elshanshamil@gmail.com
}

\title{
PROTECTIVE PROPERTIES OF THE NICKEL (II) COMPLEX WITH TRYPTOPHAN
}

Aim. The synthesized and characterized of the complex nickel (II) with tryptophan $\left[\mathrm{NiL}_{2}\right.$ $\left.\left(\mathrm{H}_{2} \mathrm{O}\right)_{2}\right] ; \mathrm{L}=$ Trp. It is shown that the composition of the complex obtained depends on the ratio of the initial components. Methods. The composition and structure of the complex were studied by elemental, TG/DrTG-DTA analysis and IR spectroscopy. The method of IR showed that the ligand in the composition of the metal complex enter the neutral form and coordinate with the complexing agent through the nitrogen atom. Results. The results of thermogravimetric studies have shown that the final product of the thermal decomposition of all compound is metal oxide, respectively. Conclusions. Have been studied the biological properties - the toxicity has been evaluated, the influence of the complex on the resistance to hypoxia and ant radiation activity has been determined.

Keywords: tryptophan, nickel, tryptophanmetal complexes, amine groups, IR spectroscopy, thermogravimetry, toxicity, antiradiation activity.

A systematic study of a number of metal complexes and various organic compounds of both synthetic and natural origin made it possible to develop a new class of metal-containing drugs, which are the most promising. Research in this area is based on the use of model biologically active molecules containing functional groups characteristic of biological systems.

This principle makes it possible to reveal the dependence of the coordination capabilities of ligands on the nature of the metal, to determine the effect of the nature of the ligand on the nature of the formed coordination sites, to formulate chemical and biological criteria for the selection of compounds that are most promising for practical use.

One of the main causes of harmful side effects caused by drugs is the formation of endogenous metal-drug (ML) complexes within the body, which are the transport form of the drug. The consequence of the formation of low molecular weight complexes is the destruction of metalloenzymes (ML), metalloprotein or other metalloorganel.

Reactions of this type can be accompanied by a change in the function of metalloenzymes (MF) and other metalloorganel. The same complexes of ML synthesized outside the body (exogenous) are devoid of the ability to destroy organometallic organelles, therefore they are less toxic and more therapeutically active than their constituent drugs. The synthesis of coordination compounds of biogenic elements with biologically active ligands containing various functional groups $(-\mathrm{SH} ;-\mathrm{OH} ;-\mathrm{COOH} ;-\mathrm{NH} 2)$ is one of the promising areas of biocoordination chemistry.

There is a significant amount of work indicating the interaction of metal complexes with free radicals. It has been shown on model systems that MLn complexes serve as traps for free radicals, converting them into non-radical products, complexes of non-transition metals disproportionate the radicals.

The study of the properties and structure of coordination compounds of metal ions with organic ligands containing various donor centers was an important factor in the development of new approaches to their physico-chemical research [1-3].

On the other hand, complex compounds of many transition elements can possess a wide range of useful properties, for which the chemistry of complex compounds has not yet been sufficiently studied [4]. Complexes of transition metals with amino acids in proteins and peptides are utilized in numerous biological processes, such as oxygen conveyer, electron transfer and oxidation. In these processes, the enzymatic active site, which is very specific, forms complexes with divalent metal ions. Coordination of amino acids to metal ions is well known, with strong binding to transition metals oc-

\footnotetext{
- SHAMilov E. N., AbDUllaev A. S., SHAMilli V. E., ASGERova T. Y., GAHRAMANOVA Sh. I., JALALADDINOV F. F.
} 
curring via a chelate binding mode involving both carboxylate and amine groups.

The metal complexes of many transition elements can possess a wide range of useful properties, for which the chemistry of complex compounds has not yet been sufficiently studied.

Tryptophan - is a proteinogenic amino acid and is part of the proteins of all known living organisms, plays protective functions, which is very important under the action of various stress factors, including radiation. Therefore, the synthesis of new biologically active derivatives of tryptophan is extremely important.

In past works we have synthesized complexes of manganese (II), copper (II), cobalt (II) zinc (II) with tryptophan, studied them antiradiation properties [5].

The purpose of was to obtain, assess toxicity, determine the effect on resistance to hypoxia and antiradiation activity of the nickel (II) tryptophan complex.

\section{Material and methods}

Measurement methods. The composition and the proposed structure of the complex were studied by elemental, thermogravimetric (NETZSCH STA 449F3 STA449FSA-0622-M) analysis (ICP-MS); and by infrared spectroscopy ("Specord M-80" from Carl Zeiss).

\section{Experimental part}

For the synthesis of nickel (II) -tryptophanate, sodium tryptophanate was obtained in the first stage. Then, at the second stage, nickel (II) tryptophanate was isolated during the interaction of nickel chloride with the obtained sodium salt.

\section{Results and discussion}

X-ray phase analysis of nickel (II)tryptophanate showed the individuality of the resulting complex.

\section{Elemental analysis}

The elemental analysis data of the metalligand complexes are pointed up in Tables 1, 2.

Infrared (IR) Spectroscopy

To determine the coordination character of the synthesized complex compound formed between the ligand and of nickel (II) IR spectroscopic analysis was carried out. The strong and broad absorption band in the range of $3600-3000 \mathrm{~cm}-1$ cor- respond to asymmetric and symmetric stretching vibrations of aqua molecules. At the range of 3392 $\mathrm{cm}^{-}{ }^{1}$ and $3161 \mathrm{~cm}^{-}{ }^{1}$ bands are belonging to N-H stretches of $\mathrm{NH}_{2}$ group of tryptophan. The weak bands at the range of $2936-2906 \mathrm{~cm}^{-1}$ are attributed to the $\mathrm{CH}_{2}$ vibrations. In complex, tryptophan ligands are coordinated to the metal ion as monodentate by carboxylic group. The (COO-) asym. peaks are $1609 \mathrm{~cm}^{-}{ }^{1}$ for $\mathrm{Ni}(\mathrm{II}),(\mathrm{COO}-)$ sym peaks are $1461 \mathrm{~cm}^{-1}$ for $\mathrm{Ni}(\mathrm{II})$.

The low-intensity bands in the region of $600-400 \mathrm{~cm}^{-}{ }^{1}$ are attributed to $\mathrm{M}-\mathrm{N}$ and $\mathrm{M}-\mathrm{O}$ vibration.

When comparing the IR spectra of nickel (II) chloride, tryptophan, and the complex, new bands appear (from 1200 to $1000 \mathrm{~cm} \mathrm{"1),} \mathrm{which} \mathrm{are} \mathrm{ab-}$ sent in the spectra of tryptophan and chloride. It is known from the literature that coordination bond bands are characteristic in this region. metalnitrogen, the band of the free carboxyl group disappears in the absorption spectrum, while the appearance of new bands of the coordination bond Me-N is characteristic. Such changes in the IR spectra are characteristic of almost all complexes of tryptophan with metals. On this basis, we can assume that complexation proceeds through amino and carboxyl group.

\section{Biogical properties}

Assessment of toxicity

Toxicity assessment Experiments were carried out on Wistar rats of both sexes weighing 150$180 \mathrm{~g}$. Acute toxicity of the complex was determined according to the method $[6,10]$, with a single intragastric administration in doses in a final volume of $10 \mathrm{ml} / \mathrm{kg}$. The nickel complex was injected once intragastrically in volumes of 1.0-5.0 $\mathrm{ml} / \mathrm{kg}$. Animals of the control group received an equivalent volume of purified water. Observation of the animals was carried out within two weeks, the moment of administration of the test agent. Observed the general condition and behavior of animals, recorded visible signs of intoxication and the number of dead animals with examination of internal organs and histological examination of vital organs in the event of death of animals. The criteria for assessing "acute" toxicity were the picture of intoxication and survival of animals, as well as the state of internal organs. 
Protective properties of the nickel (II) complex with tryptophan

Table 1. Elemental analysis results of the complexes

\begin{tabular}{|c|c|c|c|c|c|c|c|c|}
\hline \multirow{2}{*}{$\begin{array}{c}\text { Symbolic } \\
\text { formula }\end{array}$} & \multirow{2}{*}{$\begin{array}{c}\text { Molecular } \\
\text { weight }\end{array}$} & \multicolumn{2}{|c|}{$\% \mathrm{Cl}$} & \multicolumn{2}{|c|}{$\% \mathrm{H}$} & \multicolumn{2}{c|}{$\% \mathrm{~N}$} & Color \\
\cline { 3 - 9 } & Calc. & Meas. & Calc. & Meas. & Calc. & Meas. & \multirow{2}{*}{ Green } \\
\hline $\begin{array}{l}{\left[\mathrm{NiL}_{2} \quad\left(\mathrm{H}_{2} \mathrm{O}\right)_{2}\right]} \\
\mathrm{L}=\text { Trp }\end{array}$ & 501.15 & 52.27 & 52.68 & 5.12 & 5.19 & 10.76 & 11.17 & \\
\hline
\end{tabular}

Table 2. Thermoanalytical results (TG/DrTG and DTA) for the nickel (II)-tryptophanate complex

\begin{tabular}{|c|c|c|c|c|c|c|c|c|}
\hline Complex & $\begin{array}{c}\text { Temp. } \\
\text { Range }\left({ }^{\circ} \mathrm{C}\right)\end{array}$ & $\begin{array}{c}\text { Removed } \\
\text { Group }\end{array}$ & $\begin{array}{c}\text { Mass } \\
\text { Loos } \%\end{array}$ & $\begin{array}{c}\text { Found } \\
\text { Cals }\end{array}$ & $\begin{array}{c}\text { Total } \\
\text { Loos\% }\end{array}$ & $\begin{array}{c}\text { Found } \\
\text { Cals }\end{array}$ & $\begin{array}{c}\text { Decomp } \\
\text { Product }\end{array}$ & Color \\
\hline $\begin{array}{c}\left.\text { C } \mathrm{NiL}_{2}\left(\mathrm{H}_{2} \mathrm{O}\right)_{2}\right] ; \\
\mathrm{L}=\mathrm{Trp}\end{array}$ \\
\hline 1 & $150-198$ & $2 \mathrm{H}_{2} \mathrm{O}$ & 6.59 & 7.06 & & & & green \\
\hline 2 & $266-695$ & $2 \operatorname{trp}$ & 79.21 & 80.78 & 85.8 & 87.78 & $\mathrm{NiO}$ & black \\
\hline
\end{tabular}

It was found that the intragastric administration of the test nickel (II) complex in the indicated doses and volumes did not cause death of the animals during the entire observation period. In addition, no visible signs of intoxication were observed in rats receiving the test nickel (II) complex; behavioral reactions and general condition did not differ from those in the control group; the animals of the experimental groups remained active, ate well, and the stool was normal during the entire observation period. The data obtained make it possible to classify the nickel (II) complex with tryptophan to the group of practically non-toxic substances according to the classification [7].

Deermination of the effect on resistance to hypoxia

Resistance to hypercapnic hypoxia was determined in Wistar rats of both sexes weighing $150-180 \mathrm{~g}$. Hypercapnic hypoxia was modeled in a heat chamber by the method [8]. The test agents were administered to the animals of the experimental groups intragastrically: a powder of a complex of nickel (II) with tryptophan - in doses of 30, 60, and $90 \mathrm{mg} / \mathrm{kg}$, and also in a solution of $0.1 ; 0.5$ and $1.0 \mathrm{ml} / \mathrm{kg}$ for 10 days, once a day (Table 3). Animals of the control group received a similar dose of purified water. During the experiments, under hypercapnia conditions, the life expectancy of animals was assessed.

\section{Atiradiation activity}

The antiradical activity of the test samples was determined IN VITRO, by inhibition of 1,1diphenyl-2-picrylhydrazyl radicals (DPPH). The literature describes various methods for determining the antiradical activity of potential antioxidants. In this work, one of the most popular methods was used for a quantitative assessment, based on the reaction of a stable free radical DPPH (2,2'diphenyl-1-picrylhydrazyl), dissolved in ethanol, with an antioxidant sample $(\mathrm{AO}=\mathrm{AN})$ according to the scheme:

$\mathrm{DPPG}^{*}+\mathrm{AH} \rightarrow \mathrm{DPPG}-\mathrm{H}+\mathrm{A} *$.

A solution of DPPH in ethanol has an absorption maximum at $517 \mathrm{~nm}$ (violet).

The progress of the reaction was monitored by the change in the optical density of the solutions by spectrophotometry. As a result of the reduction of DPPH with an antioxidant, the intense violet color of the DPPH solution in ethanol at $\lambda=517$ $\mathrm{nm}$ in the visible region of the spectrum decreases. In this case, the DPPH radical, interacting with the antioxidant molecule, passes into a non-radical form.

Ethanol was chosen as a solvent, in which it was found that the reproducibility of the results obtained in ethanol was twice as high as in methanol.

The studies were carried out on a Specord UV VIS spectrophotometer in cuvettes $1=1.0 \mathrm{~cm}$ at $\mathrm{t}=20^{\circ} \mathrm{C}$.

To determine the inhibition of 2,2-diphenyl1-picrylhydrazyl radical (DPPH) to $0.1 \mathrm{ml}$ of the test sample in the concentration range of $0.1 ; 0.25$; $0.5 ; 0.75 ; 1 \mathrm{mg} / \mathrm{ml}$ was added $3 \mathrm{ml}$ of a $6 \times 10^{-} 5 \mathrm{M}$ radical solution. Experiments were carried out in test tubes wrapped in black polyethylene. After vigorous stirring, the solutions were left in the dark, and after 30 minutes the optical density was measured at a wavelength of $517 \mathrm{~nm}$.

The antiradical effect was assessed by the percentage of inhibition of DPPH radicals, calculated as the ratio of the change in the optical density of an alcohol solution of 1,1-diphenyl-2picrylhydrazyl (DPPH) upon addition of the test samples.

$$
\mathrm{A}=[(\mathrm{Ac}-\mathrm{Ai}) / \mathrm{Ac}] \times 100 \%,
$$

where $\mathrm{A}$ is antiradical activity (\%); Ac is the optical density of the initial DPPG solution (posi- 
tive control); $\mathrm{Ai}$ is the optical density of the DPPG solution after adding the test sample.

The concentration-dependent optical density of the test solutions was measured on a spectrophotometer at a wavelength of $520 \mathrm{~nm}$. The values of the optical density of solutions of the nickel (II) complex with tryptophan at concentrations of 0.10 , $0.25,0.50,0.75$, and $1.00 \mathrm{mg} / \mathrm{ml}$, obtained experimentally, are shown in Table 4.

The antiradical activity of the test solutions was compared with the antiradical activity of butyl- hydroxyanisole (BHA). The values of the antiradical effect calculated according to the above formula (1) and are shown in Table 5.

\section{Conclusions}

Thus, as a result of the experiments carried out and the data obtained, one can come to the conclusion that the complex of tryptophan with nickel (II) has noticeable radioprotective properties.

Table 3. The effect of the complex of nickel (II) with tryptophan on the lifespan of rats with hypercapnic hypoxia

\begin{tabular}{|c|c|c|c|c|}
\hline \multirow[b]{2}{*}{$\begin{array}{l}\text { № } \\
\text { o/n }\end{array}$} & \multirow[b]{2}{*}{ Animal groups } & \multirow[b]{2}{*}{ Doses } & \multicolumn{2}{|c|}{ life span, minutes } \\
\hline & & & single [acute] dosing & $\begin{array}{l}\text { multiple-dose intro- } \\
\text { duction }\end{array}$ \\
\hline 1 & Control & - & - & 26,7 \\
\hline 2 & $\begin{array}{l}\text { Nickel (II) complex with trypto- } \\
\text { phan }\end{array}$ & $\begin{array}{l}30 \mathrm{mg} / \mathrm{kg} \\
60 \mathrm{mg} / \mathrm{kg} \\
90 \mathrm{mg} / \mathrm{kg}\end{array}$ & $\begin{array}{l}24,8 \\
26,0 \\
25,4\end{array}$ & $\begin{array}{l}27,8 \\
34,6 \\
41,1 \\
\end{array}$ \\
\hline 3 & Nickel (II) complex, solution & $\begin{array}{l}0,1 \mathrm{ml} / \mathrm{kg} \\
0.5 \mathrm{ml} / \mathrm{kg} \\
1,0 \mathrm{ml} / \mathrm{kg}\end{array}$ & $\begin{array}{l}31,7 \\
38,6 \\
43,0\end{array}$ & $\begin{array}{l}37,9 \\
49,4 \\
44,6\end{array}$ \\
\hline
\end{tabular}

Table 4. Change in the optical density of the complex of nickel (II) with tryptophan at different concentrations

\begin{tabular}{|c|c|c|c|c|c|}
\hline \multirow{2}{*}{ Test substances } & \multicolumn{5}{|c|}{ Concentration of substances (mg / ml) } \\
\cline { 2 - 6 } & 0,1 & 0,25 & 0,5 & 0,75 & 1,0 \\
\hline Butylhydroxyanisole (BHA) & 0,1362 & 0,1333 & 0,1257 & 0,1202 & 0,1145 \\
\hline The investigated complex & 0,0840 & 0,0861 & 0,0811 & 0,0783 & 0,0777 \\
\hline
\end{tabular}

Table 5. Antiradical activity (ARA) (\%) of the complex of nickel (II) with tryptophan at different concentrations

\begin{tabular}{|c|c|c|c|c|c|}
\hline \multirow{2}{*}{ Test substances } & \multicolumn{5}{|c|}{ Concentration of substances (mg / ml) } \\
\cline { 2 - 6 } & 0,1 & 0,25 & 0,5 & 0,75 & 1,0 \\
\hline Butylhydroxyanisole (BHA) & 78,82 & 80,11 & 82,49 & 83,08 & 83,88 \\
\hline The investigated complex & 49,89 & 51,73 & 53,27 & 54,15 & 56,93 \\
\hline
\end{tabular}

\section{References}

1. Gahramanova Sh.I., Azizov. I.V. Guliyeva.E.A., The effect of newly synthesized zinc complexes with amino acids on the morphophysiological indicators of wheat seedlings. Academic Journal of Western Siberia. 2014. Vol. 10, № 5. P. 94-95.

2. Gahramanova Sh. İ., Suleymanov G.Z., Azizov I.V. Influence Newly Syntesized Manganese Complexes with Amino Asids on Morphophysiological Chracteristics Wheat Germ. American International Journal of Contemporary Research. 2014. Vol. 4, No. 12. P. 58-60.

3. Mahmudov K. T., Sutradhar M., Martins L., Silva F. C, Ribera A., Nunes V. M., Marchetti F., Pombeiroa A. L., Gahramanova Sh. I. Mn(II) and $\mathrm{Cu}$ (II) complexes with arylhydrazones of active methylene compounds as effective heterogeneous catalysts for solvent and additive-free microwave-assisted peroxidative oxidation of alcohols. RSC Advances An international journal to further the chemical sciences. The Royal Society of Chemistry. 2015. 5. P. 25979-25987. 
4. Gahramanova Sh. I., Gulieva E.A, Suleimanov G.Z, Karimova U.A, Asgarova T. Y. Interaction of manganese (II) with valine and B-alanine. Fundamental and applied research in the field of chemistry and ecology : International Youth Scientific and Practical Conference of Students, graduate students and young (September 23-26, 2015, Kursk). Kursk, 2015. P. $29-31$.

5. Alam S.M., Shereen A. Effect of different levels of Zinc and Phosphorus on growth and chlorophyll content of wheat. Asian J. of plant sciences. 2002. № 3. P. 304-306.

6. Shamilov E.N., АбдуллаевA.S., Gahramanova Sh.I., Jalaladdinov F.F. Synthesis, characterization and antiradiation properties of the tryptophanates of cobalt (II), manganese (II), copper (II) and zinc. Factors in Experimental Evolution of Organisms. 2020. Vol. 26. P. 154-157.

7. Belenky M. L. Elements of a quantitative assessment of the pharmacological effect. L., 1963. 148 p.

8. Sidorov K.K. On the classification of toxicity of poisons with parenteral routes of administration. Toxicology of new industrial chemicals. M., 1973. S. 47-51.

9. Buresh J. Methods and basic experiments for the study of the brain and behavior. M: Higher school, 1999. 399 p.

10. Gahramanova S.I., Jalaladdinov F.F., Munshieva M.K., Khudaverdiev R.A., Hamidov R.H., Muradkhanov R.M., Abdullaev A.S., Shamilov E.N., Azizov I.V. Synthesis and Investigation of Complex Compounds of Divalent Manganese, Copper, Cobalt and Zinc with Tryptophan and their Biological Activity. Int. J. Chem. Sci. 2018. Vol. 16 (3). doi: 10.21767/0972768X.1000286.

ШАМІЛОВ Е. Н. ${ }^{1}$, АБДУЛЛАЕВ А. С. ${ }^{1}$, ШАМІЛЛІ В. Е. ${ }^{1}$, АСКЕРОВА Т. Ю. ${ }^{2}$, ГАГРАМАНОВА Ш. І. ${ }^{2}$, ДЖАЛАЛАДДІНОВ Ф. Ф. ${ }^{2}$

${ }^{1}$ Інститут радіаційних проблем Національної академї наук Азербайджану,

Азербайджанська Республіка, AZ1143, м. Баку, вул. Б. Вагабзаде, 9, e-mail: elshanshamil@gmail.com

${ }^{2}$ Інститут каталізу та неорганічної хімії ім. акад. М. Ф. Нагієва АНАН,

Азербайджанська Республіка, AZ1143, м. Баку, проспект Гусейна Джавіда, 113

\section{ЗАХИСНІ ВЛАСТИВОСТІ КОМПЛЕКСУ НІКЕЛЮ (II) 3 ТРИПТОФАНОМ}

Мета. Синтезований і охарактеризований комплекс нікелю (II) 3 триптофаном $\left[\mathrm{NiL}_{2}\left(\mathrm{H}_{2} \mathrm{O}\right)_{2}\right] ; \mathrm{L}=\mathrm{Trp}$. 3'ясовано, що склад отриманого комплексу залежить від співвідношення вихідних компонентів. Mетоди. Склад і структуру комплексу вивчено методами елементного аналізу, аналізу TG / DrTG-DTA та IЧ-спектроскопії. Метод ІЧ показав, що ліганд у складі металокомплексу входить у нейтральну форму і координується 3 комплексоутворювальним агентом через атом азоту. Результати. Термогравіметричні дослідження показали, що кінцевим продуктом термічного розкладання сполуки є оксид металу. Висновки. Вивчено біологічні властивості - оцінено токсичність, встановлено вплив комплексу на стійкість до гіпоксії та протирадіаційну активність.

Ключові слова: триптофан, нікель, комплекси триптофан-металу, аміногрупи, ІЧ-спектроскопія, термогравіметрія, токсичність, протирадіаційна активність. 